\title{
PENINGKATAN HASIL BELAJAR SISWA PADA MATERI ARITMATIKA SOSIAL DENGAN MENGGUNAKAN MODEL PEMBELAJARAN KOOPERATIF TIPE MAKE A MATCH DI KELAS VII-2 SMP NEGERI 12 AMBON
}

\author{
Alvionita Nanlohy ${ }^{1}$, Juliana S Molle ${ }^{2}$, Magy Gaspersz ${ }^{2}$ \\ 1,2 Prodi Pendidikan Matematika Fakultas Keguruan dan Ilmu Pendidikn, Universitas Pattimura \\ Jalan Ir. M. Putuhena, Kampus Unpatti, Poka, Ambon, Indonesia \\ e-mail: ${ }^{1}$ vionanlohy@gmail.com;
}

\begin{abstract}
Abstrak
Penelitian ini bertujuan untuk meningkatkan hasil belajar siswa kelas VII-2 SMP Negeri 12 Ambon pada materi Aritmatika Sosial dengan menggunakan model kooperatif tipe make a match. Sumber data dalam penelitian ini adalah siswa kelas VII-2 SMP Negeri 12 Ambon. Subjek pada penelitian ini berjumlah 7 orang. Jenis Penelitian ini adalah Penelitian Tindakan Kelas (PTK). Penelitian ini terdiri dari dua siklus dengan setiap siklus terdiri dari dua pertemuan pertemuan. Teknik pengumpulan data dalam penelitian ini diperoleh melalui observasi dan tes akhir setiap siklus. Hasil tes akhir siklus I yang mencapai kriteria ketuntasan dengan memperoleh persentase hasil belajar $>65 \%$ adalah 1 subjek, kemudian pada siklus II, semua subjek ( 7 subjek) mencapai kriteria ketuntasan dengan memperoleh persentase hasil belajar $>65 \%$. Hasil belajar siswa dari siklus I ke siklus II mengalami peningkatan sebesar 85,71\%. Berdasarkan hasil yang diperoleh, maka dapat disimpulkan bahwa hasil belajar siswa pada materi aritmatika sosial dapat ditingkatkan menggunakan model pembelajaran kooperatif tipe make a match di kelas VII-2 SMP Negeri 12 Ambon
\end{abstract}

Kata Kunci: model kooperatif tipe make a match, aritmatika sosial

\begin{abstract}
This study aims to improve student learning outcomes in grades VII-2 Ambon 12th Middle School in Social Arithmetic using the make a match type cooperative model. The data source in this study is students of grades VII-2 Ambon 12th Middle School. The subjects in this study were 7 people. This type of research is Classroom Action Research (CAR). This study consisted of two cycles, with each cycle consisting of two meetings. Data collection techniques in this study were obtained through observation and the final test of each cycle. The results of the end of the first cycle test that reached the completeness criteria by obtaining the percentage of learning outcomes $>65 \%$ were 1 subject, then in cycle II, all subjects ( 7 subjects) achieved the completeness criteria by obtaining a percentage of learning outcomes $>65 \%$. Student learning outcomes from cycle I to cycle II increased by $85.71 \%$. Based on the results obtained, it can be concluded that student learning outcomes on social arithmetic material can be rise using the make a match type cooperative learning model in class VII-2 Ambon 12th Middle School
\end{abstract}

Keywords: cooperative learning model type make a match, social arithmetic

\section{Pendahuluan}

Matematika sebagai ilmu dasar, baik aspek terapannya maupun aspek penalarannya, mempunyai peranan penting dalam upaya penguasaan ilmu dan teknologi. Soedjadi (2000:43) mengemukakan bahwa tujuan umum diberikannya matematika di sekolah adalah, (1) untuk mempersiapkan siswa agar sanggup menghadapi perubahan keadaan di dalam kehidupan dan dunia yang selalu berkembang, melalui latihan bertindak atas dasar pemikiran secara logis, rasional, kritis, cermat, jujur, efektif dan efisien, (2) untuk mempersiapkan siswa agar dapat menggunakan matematika dan pola pikir matematika dalam kehidupan sehari-hari dan dalam mempelajari berbagai ilmu pengetahuan.

Proses pembelajaran matematika di sekolah ada dalam suatu sistem pendidikan, dimana dalam rangka menerapkan pendidikan yang bermutu, pemerintah telah menetapkan kurikulum tahun 
2013 untuk diterapkan pada sekolah/madrasah. Menurut Hosnan (2014:2), pengembangan kurikulum 2013 bertujuan untuk mendorong siswa agar mampu lebih baik dalam melakukan observasi, memiliki keterampilan bertanya, memiliki daya nalar dan dapat mempresentasikan apa yang diperoleh atau diketahui setelah siswa menerima materi pembelajaran di sekolah. Kusnadi (2014:127) menyatakan bahwa Implementasi Kurikulum 2013 dalam proses pembelajaran matematika merupakan pelaksanaan program kurikulum ke dalam praktik pembelajaran matematika, sehingga terjadi perubahan dalam diri peserta didik baik perubahan pengetahuan, keterampilan maupun sikap.

Dalam mempelajari matematika siswa bukan saja dituntut sekedar menghitung, tetapi juga dituntut agar lebih mampu menghadapi berbagai masalah dalam hidup ini. Menurut Dewiyani (Farida, 2015:43), masalah dalam matematika adalah pertanyaan atau soal yang harus dijawab atau direspon. Selanjutnya Jackson (2017) menyatakan bahwa masalah matematika juga membantu siswa mengaitkan pengetahuan yang dipelajari dalam kelas dengan kehidupan seharihari dan dengan pengetahuan lainnya. Dimana menurut Bornok Sinaga dkk (2017:43) banyak permasalahan dalam kehidupan nyata yang menyatu dengan fakta dan lingkungan budaya kita. Yana dkk (2018:61) juga mengungkapkan bahwa setiap siswa diharapkan dapat memahami konsep yang ada dalam setiap materi dan menerapkan konsep tersebut pada masalah di kehidupan seharihari.

Russefendi (Husna dkk, 2017:176) menyatakan bahwa matematika bagi siswa pada umumnya merupakan mata pelajaran yang tidak disenangi, dianggap sebagai ilmu yang sukar. Menurut Trianto (2015:7), ini disebabkan karena siswa tidak diajarkan dengan strategi belajar atau model pembelajaran yang membuat siswa dapat memahami bagaimana belajar, berpikir dan memotivasi diri sendiri. Adapun sebagian siswa belum menyadari akan pentingnya penguasaan matematika sehingga siswa kurang apresiatif terhadap matematika dan dalam mengikuti pembelajaran matematika.

Wahyuni (2014:90) mengungkapkan bahwa realitas yang masih berkembang

tentang dunia pengajaran di Indonesia adalah bahwa dalam pembelajaran di sekolah guru masih menggunakan cara-cara tradisional atau konvensional. Model konvensional pada sistem pengajaran dapat dilihat dari kegiatan siswa selama berlangsungnya pembelajaran, antara lain bekerja untuk dirinya sendiri, mata ke papan tulis dan penuh perhatian, mendengarkan guru dengan seksama, dan belajar hanya dari guru atau bahan ajar.

Berdasarkan pendapat-pendapat di atas, maka dalam penelitian ini peneliti memilih salah satu materi matematika sekolah menengah pertama (SMP) yang banyak sekali penerapannya dalam kehidupan sehari-hari dan dipilih berdasarkan silabus semester genap tahun ajaran 2018/2019 sesuai dengan kurikulum 2013 yaitu materi Aritmatika Sosial sebagai materi penelitian. Alasan peneliti memilih materi ini adalah karena dalam kehidupan sehari-hari sering kita temukan pemanfaatan konsep aritmatika sosial yang digunakan untuk memecahkan masalah dalam kehidupan sehingga membutuhkan pengetahuan yang baik tentang materi ini. Materi aritmatika sosial juga sering ditemui dalan soal-soal ujian nasional, seleksi masuk perguruan tinggi, maupun olimpiade tingkat nasional. Permasalahan yang muncul dalam konsep aritmatika sosial adalah penerapan konsep pada soal cerita yang membuat siswa sulit untuk memahami soal, diamana menurut Farida (2015:43) kesulitan juga banyak dialami siswa dalam menyelesaikan masalah yang berkenaan dengan soal cerita.

Untuk membantu peneliti mendapatkan informasi tentang hasil belajar materi aritmatika sosial dalam pembelajaran, peneliti melakukan wawancara tidak terstruktur dengan bapak AS salah satu guru matematika yang mengajar di kelas VII SMP Negeri 12 Ambon pada tanggal 23 februari 2019, beliau mengemukakan bahwa aritmatika sosial merupakan salah satu materi matematika yang dianggap sulit oleh siswa. Berdasarkan pengalaman, beliau mengungkapkan bahwa siswa sering melakukan kesalahan dalam memahami soal aritmatika sosial yang diberikan dalam bentuk soal cerita, dan juga dalam menentukan rumus yang mengakibatkan rendahnya hasil belajar siswa. Guru juga menjelaskan bahwa kendala yang dihadapi guru yaitu siswa cenderung tidak bertanya pada saat diberikan kesempatan untuk bertanya meskipun ternyata siswa belum mengerti tentang materi yang disampaikan guru.

Hal ini perlu mendapat perhatian dari guru agar dapat memperbaiki cara mengajar dan menciptakan suasana kondusif di kelas. Untuk mewujudkan proses pembelajaran yang kreatif perlu digunakan model pembelajaran dan media pembelajaran untuk memotivasi siswa belajar sehingga membuat siswa terlibat aktif dalam kelas dan dapat meningkatkan hasil belajar siswa. Joyce \&Weil (Rusman, 2016:132) berpendapat bahwa 
model pembelajaran adalah suatu rencana atau pola yang dapat digunakan untuk membentuk kurikulum (rencana pembelajaran jangka panjang), merancang bahan-bahan pembelajaran, dan membimbing pembelajaran di kelas. Model pembelajaran yang dapat membuat siswa lebih aktif yaitu model pembelajaran kooperatif. Menurut Johnson\&Johnson (Trianto, 2015:109), tujuan utama belajar kooperatif adalah memaksimalkan belajar siswa untuk peningkatan hasil belajar dan pemahaman baik secara individu maupun secara kelompok.

Salah satu tipe model pembelajaran kooperatif adalah model make a match. Rusman (2016:223) mengungkapkan bahwa keunggulan model ini yaitu siswa mencari pasangan sambil belajar mengenai suatu konsep atau materi pelajaran dengan menggunakan media kartu soal dan jawaban. Menurut Huda (Shafira dkk, 2018:188) model make a match dapat meningkatkan aktivitas belajar siswa, baik secara kognitif maupun fisik karena terdapat unsur permainan dan menjadikan model ini menyenangkan. Menurut Shafira (2018:189), pembelajaran model make a match melibatkan siswa sepenuhnya karena guru disini berlaku sebagai pembimbing jalannya diskusi dalam mencocokkan jawaban siswa dengan menggunakan media pembelajaran yaitu kartu (soal/jawab).

Susanti dkk (2014:260) berpendapat bahwa model make a match merupakan salah satu alternatif yang dapat diterapkan kepada siswa dalam proses belajar mengajar. Secara garis besar metode make a match adalah teknik belajar mencari pasangan, siswa mencari pasangan sambil belajar. Dalam metode ini siswa diberi kesempatan untuk membagi ide-ide dan mempertimbangkan jawaban yang paling tepat. Dengan metode pembelajaran yang sesuai ini, menjadikan kelas lebih kondusif dan siswa semakin semangat dalam belajar, hingga diperoleh hasil belajar yang memuaskan. Untuk itu dengan menggunakan model pembelajaran kooperatif tipe make a match dapat membantu siswa memahami konsep pelajaran karena siswa bukan saja mendengar penjelasan guru, namun siswa dapat belajar dan terlibat aktif baik dalam kelompok kecil melalui permainan dengan menggunakan media pembelajaran.

\section{Metode Penelitian}

Penelitian ini merupakan penelitian kualitatif dengan tipe Penelitian Tindakan Kelas (PTK). Tutuhatunewa\&Laurens $\quad$ (2016:4) penelitian tindakan kelas (PTK) adalah suatu jenis penelitian reflektif yang melibatkan suatu tindakan (treatment) yang diberikan pada peserta didik. Dalam penelitian ini digunakan model penelitian tindakan kelas (PTK) yang dikemukakan oleh Kemmis dan McTaggart dalam Tutuhatunewa\&Laurens (2016:14), yang terdiri dari empat komponen, yaitu perencanaan, tindakan, pengamatan dan refleksi.

Penelitian ini dilaksanakan pada semester genap tahun ajaran 2018/2019, yaitu pada tanggal 7 Mei sampai dengan tanggal 7 Juni 2019. Sumber data dalam penelitian ini adalah siswa kelas VII-2 SMP Negeri 12 Ambon tahun ajaran 2018/2019 yang berjumlah 31 orang dan dipilih 7 orang siswa sebagai subjek penelitian dengan kriteria pemilihannya yaitu: (1) mempunyai nilai Ujian Tengah Semester (UTS) rendah, $\quad$ (2) siswa yang mempunyai kemampuan rendah berdasarkan informasi dan pertimbangan guru mata pelajaran matematika di kelas VII-2. Dalam penelitian ini dilaksanakan 2 siklus dengan tiap siklus terdiri dari 2 pertemuan. Instrument penelitian berupa instrument tes dan lembar observasi siswa dan guru.Teknik pengumpulan data dalam penelitian ini adalah tes, pengamatan partisipan dan dokumentasi. Teknik analisis data yang digunakan dalam penelitian ini adalah analisis data kuantitatif dan teknis analisis data kualitatif sebagai berikut.

\section{a. Analisis data kuantitatif}

Analisis data kuantitatif menggunakan statistik deskriptif dimana menurut Arikunto (Dwi\&Henny, 2017:213), untuk menghitung nilai tiap siswa atau hasil belajar siswa yang dilakukan pada setiap akhir siklus tindakan dengan memberikan soal tes uraian menggunakan rumus,

$$
\text { Hasil Belajar }=\frac{\text { jumlah skor yang diperoleh }}{\text { jumlah skor total }} \times 100 \%
$$

\section{b. Analisis data kuantitatif}

Miles dan Huberman (Muhamad Ridwan, 2017), mengemukakan aktivitas dalam analisis data kualitatif, yaitu Reduksi data, Display data/penyajian datan dan Verifikasi/mengambil kesimpulan.

Usman (Siti, 2018:137) menyatakan bahwa suatu individu dikatakan tuntas belajar jika persentase daya serap individu telah mencapai skor $65 \%$, sehingga pelaksanaan tindakan perbaikan dalam penelitian berhasil jika persentase hasil belajar subjek $>65 \%$.

\section{Hasil dan Pembahasan}


Langkah awal sebelum penelitian berlangsung, terlebih dahulu peneliti membangun komunikasi dengan guru mata pelajaran di kelas VII-2 SMP Negeri 12 Ambon untuk pemilihan subjek penelitan dan pembagian kelompok dimana subjek yang dipilih akan disebarkan dalam kelompok

\subsection{Siklus I}

\section{Perencanaan}

Sebelum melaksanakan tindakan pada siklus I, peneliti dan guru membuat perencanaan dengan menyiapkan RPP yang disusun sesuai dengan langkah-langkah model kooperatif tipe make a match, bahan ajar, kartu soal dan kartu jawab dimana masing-masing disiapkan untuk pertemuan pertama dan pertemuan kedua. Menyiapkan soal tes akhir siklus I dan menetapkan kriteria penilaian yaitu tindakan dikatakan berhasil jika persentase hasil belajar subjek penelitian $>65 \%$, dan melakukan remedial jika subjek belum memenuhi kriteria penilaian.

\section{Pelaksanaan Tindakan}

Pelaksanaan tindakan pada siklus I dilaksanakan dalam dua kali pertemuan. Pertemuan pertama berlangsung pada tanggal 8 Mei 2019 dan membahas tentang materi nilai keseluruhan, nilai unit, nilai sebagian, harga pembelian dan harga penjualan, keuntungan dan kerugian, persentase keuntungan dan persentase kerugian. Sedangkan pertemuan kedua berlangsung pada tanggal 10 Mei 2019 dan membahas materi diskon (rabat), bruto, tara dan neto. Proses pembelajaran setiap pertemuan berlangsung selama 3 jam pelajaran (3x45 menit). Pada akhir pertemuan kedua diberikan tes akhir siklus I dengan menggunakan soal akhir siklus I.

\section{Observasi}

Tahap observasi dilakukan pada saat pelaksanaan tindakan berlangsung. Pengamatan pada penelitian ini dilakukan oleh 4 observer. Tiga observer bertugas mengamati siswa dan atu observer bertugas mnegawasi guru dalam proses pembelajaran di kelas dengan menggunakan lembar observasi yang disusun berdasarkan karakteristik model kooperatif tipe make a match

\section{Observasi Terhadap Guru dan Siswa}

Proses pengamatan terhadap guru pada pertemuan pertama dan kedua, sesuai dengan rancangan proses pembelajaran yang digunakan yaitu RPP 01, ditemukan beberapa hal yang belum dilakukan guru sesuai dengan RPP 01. Pada pertemuan pertama dalam kegiatan inti setelah guru menjelaskan materi pada bahan ajar (BA 01) guru tidak memberi kesempatan kepada siswa untuk bertanya dan melanjutkan dengan permainan mencari pasangan. Dalam proses menerangkan guru terlalu cepat, guru tidak tegas dalam proses pembelajaran dan hanya fokus pada siswa yang duduk di kursi bagian depan, guru juga tidak memperhatikan subjek penelitian sehingga siswa yang duduk di kursi bagian belakang dapat bercerita., hal ini mebuat kelas menjadi tidak kondusif, begitupun pada pertemuan kedua.

Proses pengamatan terhadap siswa ditemukan dalam proses pembelajaran pada pertemuan pertama dan kedua untuk setiap kelompok hanya beberapa siswa dalam kelompok saja yang serius mengikuti pelajaran dan mendengar penjelasan guru begitupun dengan subjek penelitian. Siswa dalam kelompok 3 dan 5 pada pertemuan pertama melakukan kesalahan dalam permainan mencari pasangan karena salah memahami langkah-langkah permaian yang dijelaskan guru. Subjek dalam penelitian pun masih pasif saat kerja kelompok dan proses pembelajaran didominasi oleh siswa yang pandai.

\section{Refleksi Berkaitan dengan Aktivitas Guru dan Siswa}

a. Guru belum mengajar sesuai dengan langkahlangkah model pembelajaran kooperatif tipe make a match yang direncanakan

b. Penjelasan materi yang disampaikan guru terlalu cepat dan guru tidak tegas pada siswa saat diskusi kelompok sehingga banyak siswa yang bercerita.

c. Guru tidak memperhatikan siswa khususnya subjek penelitian, karena proses pembelajaran didominasi oleh siswa yang pandai.

d. Belum nampak adanya kerjasama siswa di dalam kelompok.

e. Siswa belum tertib dalam proses belajar karena masih ada yang bercerita.

f. Subjek penelitian masih pasif dalam proses pembelajaran dan juga permainan mencari pasangan, untuk itu guru harus lebih memperhatikan da memotivasi siswa terkhusus subjek penelitian dalam proses pembelajaran

\section{Hasil Tes Siklus I}

Tabel 1. Hasil tes akhir siklus I

\begin{tabular}{cccc}
\hline NO & INISIAL & SKOR & PERSENTASE \\
\hline 1 & EW & 8,5 & $56,66 \%$ \\
2 & MI & 5 & $33,33 \%$ \\
3 & FM & 10 & $66,66 \%$ \\
4 & DT & 7,5 & $50 \%$ \\
5 & AW & 5,5 & $36,66 \%$ \\
6 & LP & 8 & $53,33 \%$ \\
7 & EP & 5 & $33,33 \%$ \\
\hline
\end{tabular}


Dari hasil tes akhir siklus menunjukan bahwa terdapat 6 subjek memiliki persentase hasil belajar belum mencapai kriteria yaitu $>65 \%$. Berdasarkan hasil refleksi pada siklus I, maka akan dilakukan perbaikan pada siklus.

Hasil refleksi menunjukan bahwa tindakan I perlu direvisi sebelum dilanjutkan pada SIklus II karena hasil yang diperoleh belum maksimal. Oleh karena itu peneliti dan guru memberikan remedial kepada siswa dan subjek penelitian yang memiliki persentase $<65 \%$. Dimana remedial dilakukan tanpa mengganggu jam mata pelajaran lain. Remedial diawali dengan penjelasan kembali materi pada siklus I dan kemudian pemberian kembali soal tes akhir siklus I sebagai soal remedial

\subsection{Siklus II}

\section{Perencanaan}

Pelaksanaan tindakan siklus II dilakukan berdasarkan hasil refleksi dari pelaksanan tindakan siklus I. kelemahan dan kekurangan yang ditemuai pada siklus I diupayakan agar dapat diatasi pada pelaksanaan tindakan siklus II. Peneliti dan guru menyiapkan RPP yang disusun sesuai dengan langkah-langkah model kooperatif tipe make a match, bahan ajar, kartu soal dan kartu jawab dimana masing-masing disiapkan untuk pertemuan pertama dan pertemuan kedua. Menyiapkan soal tes akhir siklus II dan menetapkan kriteria penilaian yaitu tindakan dikatakan berhasil jika persentase hasil belajar subjek penelitian $>65 \%$, dan melakukan remedial jika subjek belum memenuhi kriteria penilaian.

\section{Pelaksanaan Tindakan}

Pelaksanaan tindakan pada siklus II dilaksanakan dalam dua kali pertemuan. Pertemuan ketiga berlangsung pada tanggal $15 \mathrm{Mei}$ 2019 dan membahas tentang materi masalah sehari-hari tentanga pembelian dan penjualan, keuntungan dan kerugian, persentase keuntungan dan persentase kerugian. Sedangkan pertemuan keempat berlangsung pada tanggal 17 Mei 2019 dan membahas materi masalah sehari-hari tentang diskon (rabat), bruto, tara dan neto. Proses pembelajaran setiap pertemuan berlangsung selama 3 jam pelajaran (3x45 menit). Pada akhir pertemuan keempat diberikan tes akhir siklus II dengan menggunakan soal akhir siklus II.

\section{Observasi Terhadap Guru dan Siswa}

Proses pengamatan terhadap guru dan siswa pada pertemuan ketiga dan keempat ditemukan bahwa guru telah melakukan proses pembelajaran sesuai dengan rencana proses pembelajaran, dalam proses belajar guru memeberikan motivasi kepada siswa dan memberikan kesempatan kepada siswa untuk bertanya dan mengkondisikan kelas dengna baik dan tertib. Guru memilih subjek penelitian sebagai perwakilan kelompok untuk mempresentasikan hasil pekerjaan kelompok sehingga dalam proses diskusi subjek dan siswa dapat berdiskusi dengan baik. Proses pengamatan terhadap siswa ditemukan siswa lebih serius dan akif bekerjasama dalam kelompok, khususnya subjek penelitian. Siswa dalam kelompok lebih memahami proses permainan mencari pasangan sehingga tidak terjadi kesalahan dalam prosesnya.

\section{Refleksi Berkaitan dengan Aktivitas Guru dan Siswa}

a. Guru sudah mengajar sesuai dengan langkahlangkah model pembelajaran kooperatif tipe make a match.

b. Guru mengkondisikan kelas dengan baik dan memilih subjek untuk mempresentasikan hasil kerja sehingga subjek dapat berperan aktif dalam pembelajaran

c. Sudah Nampak adanya kerja sama didalam kelompok

d. Siswa lebih memahami langkah-langkah permainan mencari pasangan

\section{Hasil Tes Siklus II}

Tabel 1. Hasil tes akhir siklus II

\begin{tabular}{cccc}
\hline NO & INISIAL & SKOR & PERSENTASE \\
\hline 1 & EW & 15 & $71,43 \%$ \\
2 & MI & 15 & $71,43 \%$ \\
3 & FM & 16,6 & $78,57 \%$ \\
4 & DT & 15,5 & $73,81 \%$ \\
5 & AW & 14,5 & $69,05 \%$ \\
6 & LP & 16 & $79,19 \%$ \\
7 & EP & 15,5 & $78,81 \%$ \\
\hline
\end{tabular}

Hasil tes akhir II menunjukan adanya peningkatan pada hasil belajar siswa khususnya subjek penelitian yang dilihat dari meningkatnya persentase hasil belajar subjek yaitu $>65 \%$. Berdasarkan hasil tes akhir siklus II, diketahui bahwa persentase daya serap semua subjek telah mencapai skor $>65 \%$ atau telah tuntas belajar. Maka peneliti, guru dan observer menilai bahwa pelaksanaan tindakan perbaikan pada siklus II ini telah berkasil dilaksanakan sehingga bersepakat untuk tidak melanjutkan ke siklus berikutnya.

\section{Kesimpulan}

Berdasarkan hasil dan pembahasan dalam penelitian ini maka dapat disimpulkan bahwa dengan menggunakan model pembelajaran 
kooperatif tipe make a match pada materi aritmatika sosial dapat meningkatkan hasil belajar siswa kelas VII-2 SMP Negeri 12 Ambon. Hal ini terlihat dari hasil tes akhir siklus I yang mencapai kriteria ketuntasan dengan memperoleh persentase hasil belajar $>65 \%$ adalah 1 subjek, kemudian pada siklus II, semua subjek (7subjek) mencapai kriteria ketuntasan dengan memperoleh persentase hasil belajar $>65 \%$. Maka peningkatan yang terjadi dari siklus I ke siklus II sebesar 85,71\%.

\section{Ucapan Terima Kasih}

Jika memang ada, tuliskan Ucapan Terima Kasih di sini. Untuk penulisan daftar pustaka menggunakan $A P A \sigma^{\text {th }}$ Edition (American Psychological Association) dengan ukuran font $10 \mathrm{pt}$, seperti contoh penulisan berikut:

\section{Daftar Pustaka}

Farida, Nurul. 2015. Analisis Kesalahan Siswa Smp Kelas Viii Dalam Menyelesaikan Masalah Soal Cerita Matematika. Jurnal Pendidikan Matematika, Vol. 4, No. 2, Hal.42-52.(diakses pada $\quad 19 \quad$ November 2018) http://ojs.fkip.ummetro.ac.id/index.php/matemat ika/article/viewFile/306/265

Hosnan,M. 2014. Pendekatan Saintifik dan Kontekstual Dalam Pembelajaran Abad 21. Bogor: Ghalia Indonesia.

Rusman. 2012. Belajar dan Pembelajaran berbasis computer. Bandung: Alfabeta.

Rusman.2016.

Model-Model Pembelajaran:Mengembangkan Profesionalisme Guru. Jakarta: PT RajaGrafindo Persada.

Soedjadi, R. 2000. Kiat Pendidikan Matematika di Sekolah. Jakarta: Derokterat Jenderal Pendidikan Tinggi, Depertemen Pendidikan Nasional.

Susanti, dkk. 2014. Pengaruh Pembelajaran Cooperatif Tipe Make A Match Dan Pembelajaran Konvensional Terhadap Hasil Belajar Pkn Ditinjau Dari Kemandirian Belajar Siswa Pada Mts N Di Kabupaten Kudus. Jurnal Teknologi Pendidikan Dan Pembelajaran, Vol.2, No.2, hal 257-272.

http://ejournal.upi.edu/index.php/pips/article/vie w/10165. (April 2014)

Trianto. 2015. Mendesain Model Pembelajaran Inovatif, Progresif, dan Kontekstual. Jakarta: Prenadamedia Group.

Tutuhatunewa, E dan Laurens, T. 2016. Penelitian Tindakan Kelas. Yogyakarta: Pensil Komunikasi

Wahyuni. 2014. Upaya Peningkatan Prestasi Belajar Siswa Pada Kompetensi Dasar Aritmatika Sosial Dengan Model Pembelajaran Bermain Peran. Pedagogia, $\quad$ Vol. $\quad 3, \quad$ No. 2,hal.8899.https://www.researchgate.net/publica tion/309471633 (diakses pada Agustus 2014).

Yana, dkk. 2018. Analisis Kesalahan Siswa Dalam Menyelesaikan Sola Cerita Ditinjau Dari Gaya Belajar Kinestetik. Kadikma, Vol. 9, No. 1, Hal. 61-69.

https://jurnal.unej.ac.id/index.php/kadikma/artic le/view/8024 (diakses pada April 2018) 